IRRITABLE BOWEL SYNDROME

\title{
Association between a functional polymorphism in the serotonin transporter gene and diarrhoea predominant irritable bowel syndrome in women
}

\author{
A Yeo, P Boyd, S Lumsden, T Saunders, A Handley, M Stubbins, A Knaggs, S Asquith, I Taylor, \\ B Bahari, N Crocker, R Rallan, S Varsani, D Montgomery, D H Alpers, G E Dukes, I Purvis, \\ G A Hicks
}

Gut 2004;53:1452-1458. doi: 10.1136/gut.2003.035451

See end of article for authors' affiliations

\section{Correspondence to:} $\operatorname{Dr} G$ A Hicks, Novartis Pharmaceuticals Corporation, USCDMA One Health Plaza, East Hanover, NJ 07936-1080, USA; Gareth.Hicks@ pharm. novartis.com

Revised version received 1 March 2004 Accepted for publication 17 March 2004

\begin{abstract}
Background and aims: Serotonin (5-hydroxtryptamine, 5-HT) is an important factor in gut function, playing key roles in intestinal peristalsis and secretion, and in sensory signalling in the brain-gut axis. Removal from its sites of action is mediated by a specific protein called the serotonin reuptake transporter (SERT or 5-HTT). Polymorphisms in the promoter region of the SERT gene have effects on transcriptional activity, resulting in altered 5-HT reuptake efficiency. It has been speculated that such functional polymorphisms may underlie disturbance in gut function in individuals suffering with disorders such as irritable bowel syndrome (IBS). The aim of this study was to assess the potential association between SERT polymorphisms and the diarrhoea predominant IBS (dIBS) phenotype.

Subjects: A total of 194 North American Caucasian female dIBS patients and 448 female Caucasian controls were subjected to genotyping.

Methods: Leucocyte DNA of all subjects was analysed by polymerase chain reaction based technologies for nine SERT polymorphisms, including the insertion/deletion polymorphism in the promoter (SERT-P) and the variable tandem repeat in intron 2 . Statistical analysis was performed to assess association of any SERT polymorphism allele with the dIBS phenotype.

Results: A strong genotypic association was observed between the SERT-P deletion/deletion genotype and the dIBS phenotype $\left(p=3.07 \times 10^{-5} ; n=194\right)$. None of the other polymorphisms analysed was significantly associated with the presence of disease.

Conclusions: Significant association was observed between dIBS and the SERT-P deletion/deletion genotype, suggesting that the serotonin transporter is a potential candidate gene for dIBS in women.
\end{abstract}

$\mathrm{T}$ e essential role of serotonin (5-hydroxtryptamine, 5 -HT) in gut function is well recognised, and becoming better understood (see Gershon ${ }^{1}$ for review). 5-HT is contained primarily in enterochromaffin (EC) cells in the epithelial lining of the gut, and to a lesser degree in enteric neurones of the submucosal and myenteric plexuses. Multiple subtypes of receptor for 5-HT, located on terminals and cell bodies of these neurones (see Galligan ${ }^{2}$ for review), transduce visceral stimuli into motor and secretory activity. In addition, 5-HT receptors located on terminals of extrinsic spinal $^{3}$ and vagal $^{4}$ sensory nerves are involved in the signalling of events in the gut wall to the central nervous system (CNS). EC cells have been described as "secondary sense" cells, transducing luminal stimuli by releasing 5-HT from their basolateral membranes into the vicinity of afferent nerve terminals. ${ }^{5}$ This signalling mechanism is the primary method of sensory transmission from the lumen of the gastrointestinal tract (as no afferent neurone terminals penetrate the epithelial cell layer to directly sense luminal contents) and involves secretion of large amounts of 5-HT. For this reason, there is a need for an efficient mechanism for 5-HT reuptake, to prevent overstimulation/desensitisation of the sensorimotor responses, and indeed toxicity to other organs. ${ }^{7}$ Such reuptake of serotonin into mucosal epithelial cells and enteric neurones ${ }^{8}$ is mediated by a specific transporter protein known as the serotonin reuptake transporter (SERT), 5-HT transporter (5-HTT), or solute carrier family 6 member 4 (SLC6A4). This is the same molecule as that which performs reuptake in CNS neurones. ${ }^{910}$
There are known pathophysiological consequences of excessive 5-HT release in the bowel, including diarrhoea (for example, cholera toxin induced ${ }^{11}{ }^{12}$ ) and nausea and vomiting. ${ }^{13}$ Indeed, it has also been suggested that exaggerated release of 5-HT occurs in diarrhoea predominant irritable bowel syndrome (dIBS) patients following meals, ${ }^{14}$ and a trend for correlation of such exaggerated 5-HT release with postprandial symptoms of diarrhoea, abdominal discomfort, and pain, suffered by some IBS patients, has been reported. ${ }^{15}$ Furthermore, the therapeutic benefit of antagonists at $5-\mathrm{HT}_{3}$ receptors in female IBS patients with a diarrhoea predominant symptomology ${ }^{16}$ adds to the weight of evidence implicating dysfunction of the 5-HT system in this subtype of the disease. Increased plasma 5-HT levels could result from either exaggeration of its release or reduced reuptake, or a combination of both. Indeed, evidence exists for raised numbers of 5-HT containing EC cells in some dIBS patients. ${ }^{17}{ }^{18}$ In addition, SERT dysfunction, or the recently reported ${ }^{18}$ reduction of SERT expression, could also result in

Abbreviations: 5-HT, 5-hydroxtryptamine; 5-HTT, 5-hydroxtryptamine transporter (=SERT); bp, base pair; CNS, central nervous system; clBS constipation predominant irritable bowel syndrome; del, deletion; dIBS, diarrhoea predominant irritable bowel syndrome; EC, enterochromaffin (cell); HWE, Hardy-Weinberg equilibrium; IBS, irritable bowel syndrome; ins, insertion; kb, kilo base pair; LD, linkage disequilibrium; $\mathrm{PCR}$, polymerase chain reaction; SERT, serotonin reuptake transporter (=5-HTT); SLC6A4, solute carrier family 6 member 4; SNP, single nucleotide polymorphism; VNTR, variable number of tandem repeats 
Table 1 Samples genotyped for polymorphisms in the SERT gene

\begin{tabular}{ll}
\hline Sample set & $\begin{array}{l}\text { Female } \\
\text { Caucasian } \\
\text { samples }\end{array}$ \\
\hline IBS patients & \\
$\quad$ North-American phase III clinical trials & 194 \\
(diarrhoea predominant) & \\
Controls & \\
Commercial samples & \\
$\quad$ Coriell & 48 \\
DNA Sciences Laboratories & 125 \\
GlaxoSmithKline samples & 275 \\
Total & 448 \\
\hline
\end{tabular}

raised 5-HT levels and contribute to symptoms in these patients.

Elegant genetic manipulation studies in mice have investigated the latter possibility. ${ }^{19}$ The authors found that mice in which SERT was deleted demonstrated a gut function phenotype which was markedly different from wild-type littermates. The transgenic animals displayed altered bowel habit such that either diarrhoea (the majority) or constipation was observed. Interestingly, recent reports have described polymorphisms in the SERT gene ${ }^{20}$ which lead to either up- or downregulation of its expression. Such altered expression has thus far been reported in lymphocytes, platelets, and brain tissue, ${ }^{21-23}$ and although similar changes have not yet been investigated in the gut, it is possible that they would be found here also. The possibility exists that such polymorphisms may be present in subtypes of IBS patients, and the predicted resultant changes in 5-HT content (recently reported by Moses and colleagues ${ }^{18}$ ) or function in these patients may underlie some of their symptomology and indeed response to drugs. To date, two studies have addressed these possibilities: Pata $^{24}$ reported no association between SERT polymorphisms and the presence of IBS, regardless of subtype, but identified the short/short $(\mathrm{s} / \mathrm{s})$ homozygous polymorphism as a risk factor for a constipation predominant form of the disease (cIBS) and the long/short $(\mathrm{l} / \mathrm{s})$ heterozygous polymorphism similarly for dIBS. Camilleri and colleagues ${ }^{25}$ demonstrated greater inhibition of colonic transit in response to treatment with the $5-\mathrm{HT}_{3}$ antagonist alosetron in dIBS patients with the SERT polymorphism genotype which produces increased expression of the transporter and thus presumed enhanced uptake of 5-HT. Although this study was not aimed at investigating disease association, another study from the same group, which has been reported in abstract form, ${ }^{26}$ suggested a trend towards significance for the odds ratio for the s/s polymorphism (versus the heterozygous genotype) to be associated with the presence of CIBS.

The SERT gene encoding the SERT protein is located on chromosome 17q11.2-q1. ${ }^{27} 28$ The main gene transcript of 2.5 kilo base pairs (kb) (Ensembl Accession No L05568) contains 14 exons which span approximately $31 \mathrm{~kb}$ of genomic DNA transcript. ${ }^{29}$ Some evidence of alternative transcript splicing has been reported in the literature. ${ }^{30} 31$ One of the first SERT polymorphisms characterised was the variable number of tandem repeats (VNTR) in intron 2 of the gene and consists of 17 base pair (bp) repeats. ${ }^{29}$ The SERT gene linked polymorphic region (SERT-P), originally known as 5HTT-LPR, was first reported in 1996 by Heils and colleagues. ${ }^{20}$ It consists of a $44 \mathrm{bp}$ insertion/deletion in the $5^{\prime}$ flanking promoter region of the gene creating long $(l)$ and short $(s)$ allelic variants, respectively. The polymorphism is located within a GC rich region composed of 20-23 bp repeat units with the $s$ and $l$ alleles having 14 and 16 repeats, respectively. The same study also reported evidence for allele dependent differential SERT promoter activity. Additional work has shown that cells homozygous for the insertion allele $(l / l)$ exhibit a higher uptake of serotonin compared with those having one or two copies of the deletion allele $(l / s$ or $s / s) .{ }^{22}$ Therefore, this suggests that the presence of one or more copies of the $S$ allele reduces not only the level of transcription but also levels of protein expression and reuptake of serotonin. Both the VNTR and SERT-P polymorphisms have been extensively investigated in genetic association studies for various complex behavioural traits and disorders such as bipolar disorder, obsessive-compulsive disorder, autism, schizophrenia, substance abuse, and eating disorders, ${ }^{22}{ }^{32-38}$ and perhaps more interestingly with respect to the present study, in fibromyalgia, anxiety, and depression, which are thought to be comorbid with IBS. ${ }^{31-43}$ There are few literature reports to date showing genetic evidence of a genetic risk factor in IBS (see above), although several twin studies based on questionnaires have shown that there is such a factor for the development of IBS. ${ }^{44}{ }^{45}$ In the present study, we therefore aimed to investigate the association of the IBS phenotype with nine SERT polymorphisms in a large population of IBS patients and controls.

\section{MATERIALS AND METHODS \\ Patient and control populations}

A total of 194 samples from North American Caucasian IBS patients were used in this study. These patients were a subset of subjects who participated in the GlaxoWellcome phase III clinical trials (S3BA3001 and S3BA3002) for the alosetron hydrochloride compound (Lotronex) and were willing to participate in the genetic substudy after providing fully informed consent. All patients were females (age range 1883 years) with a history of IBS (diarrhoea as the major bowel habitués). These subjects had at least six months of recurrent symptoms that fulfilled the Rome I criteria for IBS, had normal sigmoidoscopic/colonoscopic results within five years and who, during a two week baseline period, had daily mild to severe abdominal pain/discomfort, and an average stool frequency of greater than 2.5 normal to watery stools/day. Patients were excluded if they had an unstable medical disorder, another gastrointestinal disorder, a major psychiatric disorder, or substance abuse within the previous two years. Further details of the study population and results of these two trials are published elsewhere. ${ }^{46}{ }^{47}$ No samples from patients with cIBS were collected in these clinical trials.

A panel of 448 North American Caucasian random female control samples was collected from various sources (table 1). As the IBS status for these samples was largely unknown, the number of control samples collected was higher than the patient collection, allowing for an incidence of IBS of up to $20 \%$ in the general population. ${ }^{48}{ }^{49}$ As the population was not selected on the basis of their IBS status, age of onset matching was not considered necessary.

\section{Single nucleotide polymorphism (SNP) identification}

All available genomic sequence (both exonic and intronic) surrounding the SERT exons (including $10 \mathrm{~kb} \mathrm{5'}$ and 3' flanking sequence) was amplified by polymerase chain reaction (PCR) in overlapping fragments on 30 random female Caucasian DNA samples (healthy volunteers with full consent) followed by direct sequencing of the product. The resulting sequence for these samples were aligned to allow for the detection of polymorphisms in each amplified fragment of the gene. Approximately $18 \mathrm{~kb}$ of genomic sequence was screened in total and a total of 17 SNPs were identified. Seven of these were selected for genotyping on the 
Table 2 Polymorphisms in the SERT gene genotyped on the diarrhoea predominant irritable bowel syndrome case/control samples

\begin{tabular}{|c|c|c|c|c|c|c|c|}
\hline \multicolumn{8}{|c|}{ Single nucleotide polymorphisms } \\
\hline Polymorphism & $\begin{array}{l}\text { Ref SNP in } \\
\text { dbSNP }\end{array}$ & $\begin{array}{l}\text { GenBank } \\
\text { Acc No }\end{array}$ & $\begin{array}{l}\text { Sequence } \\
\text { position }\end{array}$ & Location & Allele 1 & Allele 2 & $\begin{array}{l}\text { Minor allele } \\
\text { frequency* }\end{array}$ \\
\hline 5НТТ-Т623C & ss 5607073 & $X 76753$ & bp 623 & $5^{\prime}$ end genomic & $\mathrm{T}$ & C & $C(3.1 \%)$ \\
\hline 5НТT-Т3287C & rs25533 & X76753 & bp 3287 & 5'UTR & $\mathrm{T}$ & C & $C(7.3 \%)$ \\
\hline 5HTT-G674A & ss 5607074 & U79746 & bp 674 & Intron la & G & A & $\mathrm{A}(9.4 \%)$ \\
\hline 5НТT-С867Т & rs2066713 & U79746 & bp 867 & Intron la & C & $T$ & $\mathrm{~T}(37.6 \%)$ \\
\hline 5HTT-A2631C & $\begin{array}{l}\text { SLC6A4U3, } \\
\text { rs6354 }\end{array}$ & U79746 & bp 2631 & Exon $1 \mathrm{~b}$ non-coding & A & $\mathrm{C}$ & $C(17.4 \%)$ \\
\hline 5HTT-G160A & rs140701 & $X 76758$ & bp 160 & Intron 8 & $G$ & A & $\mathrm{A}(45.8 \%)$ \\
\hline 5HTT-G769T & rs 1042173 & X76762 & bp 769 & 3' UTR & G & $\mathrm{T}$ & $G(48.6 \%)$ \\
\hline \multicolumn{8}{|c|}{ Other polymorphisms } \\
\hline Polymorphism & Reference & $\begin{array}{l}\text { GenBank } \\
\text { Acc No }\end{array}$ & $\begin{array}{l}\text { Sequence } \\
\text { position }\end{array}$ & Location & Alleles & & $\begin{array}{l}\text { Allele } \\
\text { frequencies* }\end{array}$ \\
\hline 5HTT-VNTR & 21 & & $\begin{array}{l}\text { bp } 843-1012 \\
\text { ( } n=10 \text { rep.) }\end{array}$ & Intron 2 & \multirow{2}{*}{\multicolumn{2}{|c|}{$\begin{array}{l}\mathrm{n}=9,10,11,12 \\
\text { repeats } \\
\mathrm{del}(\mathrm{s}) / \text { ins }(1)\end{array}$}} & $\begin{array}{l}9=1.0 \% ; 10=36.9 \% ; 11=0 \% \\
12=62.1 \%\end{array}$ \\
\hline SERT-P & 17 & X76753 & bp 1826-1869 (ins) & $5^{\prime}$ end genomic & & & $s=42.8 \% ; l=57.1 \%$ \\
\hline
\end{tabular}

basis of their minor allele frequency $(>5 \%)$ in the 30 samples analysed (table 2).

\section{Assay development and genotyping}

TaqMan allelic discrimination ( $5^{\prime}$ nuclease extension) assays were designed for the seven selected SNPs using the Primer Express program from Applied Biosystems. In AT nucleotide rich regions of the gene, TaqMan Turbo probes were utilised to increase the effective annealing temperature. Details of probes (Applied Biosystems, Foster City, California, USA) and primers used can be found in table 3. All assays were performed in an $8 \mu \mathrm{l}$ volume reaction, except for the 5HTTG674A assay where the reaction volume was $25 \mu \mathrm{L}$. The standard reaction mixture contained $8 \mathrm{ng}$ of genomic DNA
(25 ng for assay 5HTT-G674A), 0.6× universal PCR mastermix (Applied Biosystems), $900 \mathrm{nmol} / \mathrm{l}$ of each primer, and $100 \mathrm{nmol} / \mathrm{l}$ of both VIC- and FAM-fluorescently labelled probes $(200 \mathrm{nmol} / \mathrm{l}$ of each Turbo probe used for assays 5HTT-G160A and G769T). All assays were processed using the following standard cycling conditions: $50^{\circ} \mathrm{C}$ for two minutes, $95^{\circ} \mathrm{C}$ for 10 minutes, 40 cycles of $95^{\circ} \mathrm{C}$ for 15 seconds plus $62^{\circ} \mathrm{C}$ for 60 seconds. When cycling was finished, reactions were kept at $15^{\circ} \mathrm{C}$ until plates were analysed on an ABI7700 TaqMan machine using the SDS1.7 software.

The 17 bp VNTR in intron 2 was analysed by PCR using the primers detailed in table 3. Amplification was performed in a $25 \mu \mathrm{l}$ reaction volume containing $50 \mathrm{ng}$ of genomic DNA,

Table 3 Nucleotide sequences for assay primers and probes for polymorphisms in the SERT gene

\begin{tabular}{|c|c|c|c|c|c|}
\hline \multicolumn{6}{|c|}{ Single nucleotide polymorphisms } \\
\hline Polymorphism & Assay type & $\begin{array}{l}\text { Forward primer } \\
\text { sequence } 5^{\prime}-3^{\prime}\end{array}$ & $\begin{array}{l}\text { Reverse primer } \\
\text { sequence } 5^{\prime}-3^{\prime}\end{array}$ & $\begin{array}{l}\text { VIC probe } \\
\text { sequence 5'-3' }\end{array}$ & $\begin{array}{l}\text { Fam probe } \\
\text { sequence } 5^{\prime}-3^{\prime}\end{array}$ \\
\hline 5HTT-Т623C & TaqMan & $\begin{array}{l}\text { TGC CTC TTC CCC GGT } \\
\text { AGT G }\end{array}$ & $\begin{array}{l}\text { ATC GCC ACA AGC ACC } \\
\text { TTG TC }\end{array}$ & $\begin{array}{l}\text { GCC CCG CCT CCA ATT } \\
\text { CAG GT }\end{array}$ & $\begin{array}{l}\text { GCC CCG CCT CCA } \\
\text { GTT CAG GT }\end{array}$ \\
\hline 5НТT-Т3287C & TaqMan & CAC CCC GCC CCG TAG & GCG CTC CCG CTG GAT & $\begin{array}{l}\text { CCC TCC CTG GCG AGC } \\
\text { GC }\end{array}$ & $\begin{array}{l}\text { CCC TCC CCG GCG } \\
\text { AGC G }\end{array}$ \\
\hline 5HTT-G674A & TaqMan & $\begin{array}{l}\text { GAA TTC AGG ACT GGA } \\
\text { TGC CTT C }\end{array}$ & $\begin{array}{l}\text { AGA GGG TAG AAA ATG TGT } \\
\text { GCA GGT A }\end{array}$ & $\begin{array}{l}\text { CCT GAG AAC ACA CGT } \\
\text { TGT CCT CAA AAA T }\end{array}$ & $\begin{array}{l}\text { TCC TGA GAA CAC } \\
\text { ACA TIG TCC TCA } \\
\text { AAA ATC }\end{array}$ \\
\hline 5НTT-C867T & TaqMan & $\begin{array}{l}\text { CCT CTC CCC AAA GTA TTG } \\
\text { CTT CT }\end{array}$ & GCG TTC CCT GGC CTC TCT & $\begin{array}{l}\text { CAT TTC CCT TCC GTA } \\
\text { GAC CCT CTG G }\end{array}$ & $\begin{array}{l}\text { CGC AT TCC CTT CTG } \\
\text { TAG ACC CTC TG }\end{array}$ \\
\hline 5HTT-A2631C & TaqMan & $\begin{array}{l}\text { GCA TCA GTA ACC TGC } \\
\text { ACA CTC } \Pi C\end{array}$ & $\begin{array}{l}\text { CCA GCA ACT CCT GTG } \\
\text { GCT AAG }\end{array}$ & $\begin{array}{l}\text { TTG CT GCC CTC TAT } \\
\text { TGC AGA ATA ACA AG }\end{array}$ & $\begin{array}{l}\text { TGC TTG CCC TCT CTT } \\
\text { GCA GAA TAA CA }\end{array}$ \\
\hline 5HTT-G160A & TaqMan & $\begin{array}{l}\text { TGT GTC AAA ACC TGA } \\
\text { TIG ACA CAT AA }\end{array}$ & $\begin{array}{l}\text { GTC CTA CAA AGA TGT } \\
\text { CAC AGA GGA AA }\end{array}$ & $\begin{array}{l}\text { TGA TGA GAA TTG TAA } \\
\text { CTG TTG TTG T }\end{array}$ & $\begin{array}{l}\text { TGA TGA GAA TTA } \\
\text { TAA CTG TG TIG TG }\end{array}$ \\
\hline 5HTT-G769T & TaqMan & $\begin{array}{l}\text { CGT AGG AGA GAA CAG } \\
\text { GGA TGC TA }\end{array}$ & $\begin{array}{l}\text { CAG CAG CAC ATG GAT } \\
\text { TAG AAG GT }\end{array}$ & $\begin{array}{l}\text { TGA GTA GCA TAT AGA } \\
\text { ATT TIA TTG CTG }\end{array}$ & $\begin{array}{l}\text { CTG AGT AGC ATA } \\
\text { TAT AAT TIT ATT } \\
\text { GCT G }\end{array}$ \\
\hline \multicolumn{6}{|c|}{ Other polymorphisms } \\
\hline Polymorphism & Assay type & Forward primer & \multicolumn{3}{|l|}{ Reverse primer } \\
\hline 5HTT-VNTR & PCR & $\begin{array}{l}\text { GTC AGT ATC ACA GGC } \\
\text { TGC GAG }\end{array}$ & \multirow{2}{*}{\multicolumn{3}{|c|}{$\begin{array}{l}\text { TGT TCC TAG TCT TAC GCC AGT } \\
\text { G } \\
\text { GGC GTT GCC GCT CTG AAT GC }\end{array}$}} \\
\hline SERT-P & PCR & $\begin{array}{l}\text { GAG GGA CTG AGC TGG } \\
\text { ACA ACC AC }\end{array}$ & & & \\
\hline
\end{tabular}

5-HTT, 5-hydroxtryptamine transporter (=SERT); PCR, polymerase chain reaction; VNTR, variable number of tandem repeats. 
$\mathrm{l} \times$ Perkin-Elmer PCR buffer $\left(\right.$ no $\left.\mathrm{MgCl}_{2}\right), 1.5 \mathrm{mmol} / \mathrm{l} \mathrm{MgCl}_{2}$, $0.2 \mathrm{mmol} / \mathrm{l}$ deoxynucleotide triphosphates, $10 \mathrm{pmol}$ of each primer, and 1 unit of AmpliTaq Polymerase (Perkin-Elmer, Boston, Massachusetts, USA). DNA was denatured at $94^{\circ} \mathrm{C}$ for four minutes and subjected to 35 cycles of $94^{\circ} \mathrm{C}$ for one minute, $60^{\circ} \mathrm{C}$ for one minute, and $72^{\circ} \mathrm{C}$ for one minute, followed by a final extension at $72^{\circ} \mathrm{C}$ for 10 minutes. Amplification products ( $10 \mu \mathrm{l}$ ) were resolved by electrophoresis on $4 \%$ Nusieve 3:1 agarose gels next to a $1 \mathrm{~kb}$ DNA molecular weight standard (Life Technologies, Carlsbad, California, USA) and visualised with ethidium bromide staining. The expected product sizes for alleles 9, 10, 11, and 12 are $253 \mathrm{bp}, 270 \mathrm{bp}, 287 \mathrm{bp}$, and $304 \mathrm{bp}$, respectively.

The $44 \mathrm{bp}$ insertion/deletion polymorphism in the promoter region (SERT-P) was analysed by PCR using the primers detailed in table 3. Amplification was performed in a $25 \mu \mathrm{l}$ reaction volume containing $200 \mathrm{ng}$ of genomic DNA, $1 \times$ Perkin-Elmer PCR buffer (no $\mathrm{MgCl}_{2}$ ), $1.5 \mathrm{mmol} / \mathrm{l} \mathrm{MgCl}_{2}$, $0.2 \mathrm{mmol} / \mathrm{l}$ deoxyadenosine triphosphate, $0.2 \mathrm{mmol} / \mathrm{l}$ deoxycytidine triphosphate, $0.2 \mathrm{mmol} / \mathrm{l}$ deoxythymidine triphosphate, $0.1 \mathrm{mmol} / \mathrm{l}$ deoxyguanosine triphosphate, $0.1 \mathrm{mmol} / \mathrm{l}$ 7-deaza- deoxyguanosine triphosphate, $20 \mathrm{pmol}$ of each primer, 5\% DMSO, and 0.5 unit of AmpliTaq Polymerase (Perkin-Elmer). DNA was denatured at $95^{\circ} \mathrm{C}$ for four minutes and subjected to 35 cycles of $95^{\circ} \mathrm{C}$ for 30 seconds, $57^{\circ} \mathrm{C}$ for 30 seconds, and $72^{\circ} \mathrm{C}$ for one minute followed by a final extension at $72^{\circ} \mathrm{C}$ for seven minutes. Amplification products $(25 \mu \mathrm{l})$ were resolved by electrophoresis on $3.5 \%$ Nusieve $3: 1$ agarose gels next to a $1 \mathrm{~kb}$ DNA molecular weight standard (Life Technologies) and visualised with ethidium bromide staining. The expected product sizes for the deletion (del or $s$ ) and insertion (ins or L) alleles are $484 \mathrm{bp}$ and $528 \mathrm{bp}$, respectively.

\section{Statistical analysis}

Testing for Hardy-Weinberg equilibrium (HWE)

The genotype distribution for all SNPs for both cases and controls were tested for HWE using a $\chi^{2}$ test (comment: the test was done for the number of expected genotypes, not the frequencies).

\section{Association test}

$\chi^{2}$ tests were carried out to test for association between allele and phenotype (allelic association) and also between genotype and phenotype (genotypic association).

\section{Odds ratio}

Odds ratio and confidence intervals were estimated using SAS software.$^{50}$ We applied the methods described in chapter 2 of Stokes and colleagues, ${ }^{51}$ specifically we used the "Proc Freq" procedure using the "Measures" option. Data for the del/ins and ins/ins genotypes were collapsed into one group to form a $2 \times 2$ table of "del/del" and "non del/del" individuals against disease status.

\section{Linkage disequilibrium (LD)}

LD is a measure of the association between alleles at different loci. LD tends to decline with distance between polymorphisms and generally exists for polymorphisms that are less than $100 \mathrm{~kb}$ apart. LD was measured using $r^{252}$ and $\mathrm{D}^{\prime}$ statistics. $^{53}$

\section{RESULTS}

\section{Genotype analysis of SERT polymorphisms}

As the availability of SNPs in the public domain was limited when this study was performed, SNPs were isolated by resequencing all available genomic (exonic, intronic, untranslated region plus $10 \mathrm{~kb}$ flanking sequence) in 30 random female Caucasian DNA samples. A total of 17 SNPs were identified and a total of seven SNPs (available in the dbSNP database http://www.ncbi.nlm.nih.gov/SNP/index.html; see table 2 for SNP reference ID) were selected for genotyping on the basis of their minor allele frequency $(>5 \%)$. These seven SNPs were screened using the TaqMan $5^{\prime}$ nuclease extension assay. PCR based assays were used to screen SERT-P and VNTR polymorphisms, which were performed in duplicate to control for genotyping error. A total of 194 IBS patient samples and 448 control samples were analysed for the nine polymorphisms (table 2 ).

\section{Association between IBS disease phenotype and SERT genotypes}

Statistical analyses were performed to investigate the association between genotypes and the dIBS phenotype.

Genotype distribution for all polymorphisms was checked for deviation from HWE. Deviation was observed for the 5HTT-VNTR assay in the control study population $(p=0.0084)$. As this could suggest a problem with the assay, data related to this assay were excluded from further analysis.

Association analyses were performed for the eight remaining polymorphisms. The strongest association was observed between the $s / s$ genotype of the SERT-P polymorphism and the dIBS phenotype $\left(p=3.07 \times 10^{-5}\right)$. Table 4 shows the genotype distribution between dIBS cases and controls for this polymorphism. The percentage of $s / s$ genotypes was nearly double in dIBS cases compared with controls at the expense of the heterozygote genotypes. The odds ratio for these data was 2.23 for $s / s$ individuals versus non $-s / s$ individuals with $95 \%$ confidence limits of 1.51-3.31, respectively, providing further statistical support for an association between the $s / s$ genotype and the dIBS phenotype. Although deviation from HWE was also observed for the SERT-P polymorphism, this was seen for dIBS cases only $\left(p=3.1 \times 10^{-6}\right)$ and could be an effect of the genotypic disease association observed or the functional nature of this polymorphism. No association was observed with any of the other SERT polymorphisms.

LD analysis was performed to identify how many of the polymorphisms analysed in this study share the same block of LD (data not shown). The D' measurement of LD indicates that there may be breakdown of LD between the SERT-P and 5HTT-G674A polymorphisms. Also, none of the other polymorphisms are in perfect LD $(r$ measurement $>0.9)$ with the SERT-P polymorphisms. In fact, the only high $r$ measurement $(>0.8)$ was observed between polymorphisms 5HTT-G160A and G769T.

Although association between the dIBS phenotype and a combination of two or more SERT polymorphism alleles (also called haplotypes) was also studied, none of the haplotypes showed a more significant association compared with the single polymorphism $\mathrm{p}$ values reported here (data not shown).

Table 4 Genotype distribution and associated odds ratio for the SERT-P polymorphism in diarrhoea predominant irritable bowel syndrome (dIBS) cases and controls

\begin{tabular}{lcc}
\hline Genotype & Controls & dIBS cases \\
\hline$s / s$ & $77(17.2 \%)$ & $61(31.4 \%)$ \\
$/ / s$ & $214(47.8 \%)$ & $62(31.9 \%)$ \\
$/ / 1$ & $138(30.8 \%)$ & $63(32.5 \%)$ \\
No genotype obtained & $19(4.2 \%)$ & $8(4.1 \%)$ \\
Odds ratio $(95 \% \mathrm{Cl})$ for $s / s$ v non-s genotypes: & \\
$2.23(1.51-3.31)$ & \\
\hline
\end{tabular}




\section{DISCUSSION}

To date there has been little evidence for the involvement of genetic factors in the development of IBS. Although there have been indications from non-genetic studies that there may be familial associations in adults with IBS, including some twin studies, ${ }^{44} 4554$ no candidate genes have been associated with any IBS phenotype. Recently, Pata ${ }^{24}$ reported no association between SERT-P polymorphisms and the presence of IBS, but did suggest the short/short $(s / s)$ homozygous polymorphism as a risk factor for the constipation predominant form of the disease and the long/short $(\mathrm{l} / \mathrm{s})$ heterozygous polymorphism similarly for dIBS. Interestingly, the $s / s$ and $l / s$ variants have both been shown to lead to less transporter protein expression and less serotonin reuptake ${ }^{20} 22$ and thus the apparently opposing associations with cIBS and dIBS reported are difficult to interpret based on predicted functional consequences of the polymorphisms. The authors noted that these conclusions were drawn from very small samples $(\mathrm{n}=26$ for cIBS; $\mathrm{n}=18$ for dIBS) and as such interpretation of the results should be limited. However, in their pilot study involving 173 patients with IBS (mixed subgroup population) or chronic abdominal pain, Kim and colleague $^{26}$ also determined a trend towards an association between the $s / s$ polymorphism and the constipated (IBS) phenotype. It is not immediately obvious how a polymorphism that produces a reduced level of functional reuptake transporter, and elevated 5-HT levels, results in a constipated phenotype but plausible mechanisms do exist (see below).

In stark contrast with these earlier studies, the present data from a North American study population provides evidence of an association between the $s / s$ genotype of the SERT-P polymorphism and dIBS, which is perhaps somewhat more intuitive based on the predicted functional consequence of raised levels of 5-HT in the bowel. This study represents the first evidence for a statistically significant association between the dIBS phenotype and a polymorphism in the SERT gene. It is not known at this time whether the commonly used diagnostic distinction of IBS sufferers into constipation predominant, diarrhoea predominant, or alternators, has any true physiological or genetic basis, but further studies of this type will surely help to define this more precisely.

In our study, the distribution of the genotypes in the dIBS cases clearly reflects an increase of the $s / s$ genotype when compared with the control population. From the allelic analyses, no such association with the phenotype was found, suggesting that two alleles are required to see the effect of association. In this study and others, ${ }^{55}$ the distribution of the genotypes in the general population is biased towards the heterozygous $l / s$ form, with the $s / s$ genotype being least frequent, accounting for only approximately $18 \%$. The increased risk of carrying this genotype in the dIBS disease population appears to be at the expense of the more common heterozygous form as $l / s$ frequency is reduced and that of the $l / l$ form is unchanged. This may explain in part the lack of allelic association described above.

The few studies that have been performed in vitro to date suggest that the s allele is dominant, such that both the heterozygous $(l / s)$ and homozygous $(s / s)$ genotypes result in reduced transporter expression and thus function, compared with the $l / l$ genotype. ${ }^{20}{ }^{21}$ Therefore, if we hypothesise that such reduced SERT expression results in dIBS symptoms, then both genotypes containing the $s$ allele should be associated with the presence of the disease. This was not what we found; indeed, analysis of the differences between the frequency of combined $s / s+l / s$ relative to the $l / l$ genotype was not performed as the genotype frequencies of these two groups were virtually identical and therefore quite obviously not significantly different. The important point to stress from our analysis, as mentioned above, is the greater proportion of $s / s$ genotypes in the disease population compared with controls, apparently resulting from a shift from the $l / s$ form. The overall risk of bearing a copy of the s allele is unchanged in the disease but rather the shift from heterozygous to homozygous forms appears to be the more relevant factor. Perhaps the small trend for a greater functional consequence of the homozygous genotype in vitro (Lesch et al described a greater significance reported for the $s / s$ to $l / l$ comparison than for the $l / s$ to $l / l$ comparison) could help us understand these disease phenotype findings. However, direct correlation between in vitro findings in isolated cells and disease symptom expression is a huge leap and probably not a sensible link to try to claim.

Genotyping for the SERT-P polymorphism was performed in duplicate for all samples and the genotypes were scored in duplicate by different individuals, and thus it is unlikely that these results are due to genotyping error. This study has not determined how far the block of LD containing the SERT-P polymorphism extends upstream of the SERT gene and no LD map is available for the area surrounding the gene. Therefore, we cannot rule out the possibility that another polymorphism upstream of the SERT gene, which is in high LD with the SERT-P polymorphism, may also be associated with the dIBS phenotype. The genotypic association is also reflected in the HWE deviation observed for dIBS cases, and this method of detecting disease association in a heterogeneous disease such as IBS has been reported in the literature. ${ }^{56}$

There can be no doubt that genetic studies on populations collected during clinical trials are unfortunately far from perfectly structured due to the strict limitation on the individuals that can be collected and their willingness to be involved in a genetic analysis. In the case of this IBS study, it was not possible to collect data from cIBS patients and so the analysis and conclusions are restricted solely to the dIBS population. Collection of matched controls was also problematic but this problem was addressed by increasing the number of controls used to over twice the number of cases. We have demonstrated (unpublished data) that when matched controls are not available, an increased number of controls from a general ethnic match increases study power and suppresses confounding effects such as population stratification and admixture. However, as the SERT-P polymorphism is known to show frequency variability between ethnic groups, ${ }^{57} 58$ additional studies based around the genetic hypothesis formulated in this work should be undertaken to replicate the association demonstrated.

It is interesting to speculate how the evidence of association between the $s / s$ genotype of the SERT-P polymorphism with diarrhoea predominant IBS might provide some insight into the underlying pathophysiology of the disease, at least in this subgroup of female patients. As described above, reduced transcription of the 5-HT transporter would be expected to lead to enhanced levels of 5-HT in the bowel of these patients, which in turn might be predicted to result in increased bowel motility and secretion, and subsequent diarrhoea; a situation not dissimilar to that described for SERT knockout mice. ${ }^{19}$ Furthermore, as observed in the SERT $-/-$ mice, it is intriguing to consider the possibility that such increased 5-HT may also lead to a constipated phenotype, as suggested by earlier studies. ${ }^{24}{ }^{26}$ This may occur following 5 -HT receptor desensitisation in the presence of high levels of agonist for long periods, or indeed could be produced by excessive stimulation of the 5-HT receptor bearing enteric neurones such that the normal motility pattern is stimulated to such an extent that coordination of enteric reflexes breaks down and contractile and secretory function fail. At a cellular level, such excessive neuronal depolarisation may result in "depolarisation block". In this condition, the neuronal membrane 
potential remains depolarised above the threshold for sodium channel activation, and further action potential generation is not possible. In this way, varying degrees of excitation of enteric neurones might contribute to both hyper- and hypomotility and secretion.

The potential effects of reduced uptake of 5-HT are not however restricted to the neurones of the enteric nervous system. Excessive or prolonged stimulation of extrinsic afferents may also result in the development of neuronal sensitisation, at peripheral, spinal, or higher CNS levels, such that perception of sensations from the bowel is heightened, resulting in symptoms of urgency, bloating, and pain. Such neuronal hypersensitivity is thought to be a key factor in the generation of sensory IBS symptoms, ${ }^{5960}$ and can be mimicked in animals by repetitive physical stimulation of the bowel, or by periods of infection, ${ }^{61}{ }^{62}$ irritation/inflammation, ${ }^{63-65}$ or stress. ${ }^{6-68}$ In a similar way, repeated stimulation of either extrinsic afferent nerves by excessive 5-HT in patients with impaired reuptake may also provide another method by which sensory perception of events in the gastrointestinal tract may be inappropriately enhanced.

This study shows that the SERT polymorphism, or a polymorphism in linkage disequilibrium with the SERT polymorphism, may play a role in the development of IBS. We do not believe that the reduction in SERT is the sole cause of dIBS in our population but we do believe it might be a contributing factor. Perhaps a combination of this polymorphism with many other factors, such as raised EC cell number, could explain the variety of symptom patterns observed across the disease population. The recent finding of reduced SERT expression in IBS patient biopsies, ${ }^{18}$ coupled with our own findings, does encourage speculation that there is a role for altered transporter function in the disease. While research continues into the variety of possible factors which initiate, maintain, and exacerbate the symptoms suffered in IBS, the data reported in the present study clearly provide further support for the key role of the serotonin system in IBS pathophysiology and will hopefully stimulate further effort towards identifying and understanding further potential genetic and other factors that might contribute to the disease.

\section{ACKNOWLEDGEMENTS}

We would like to thank the Discovery Genetics Europe Sequencing Group (GlaxoSmithKline) for providing sequencing support, Rosalind Cutts and Rusty Czerwinski for data management support, and Helen Connor for advice on IBS biology. We would also like to thank Chun-fang Xu, Ian Gray, and Aruna Bansal for critical reading of the manuscript.

\footnotetext{
Authors' affiliations

A Yeo, A Handley, M Stubbins, S Asquith, I Purvis, Department of Discovery Genetics, GlaxoSmithKline, New Frontiers Science Park, Harlow, Essex, UK

P Boyd, S Lumsden, T Saunders, A Knaggs, I Taylor, B Bahari, N Crocker, R Rallan, S Varsani, D Montgomery, Department of Discovery Genetics, GlaxoSmithKline, Stevenage, Herffordshire, UK D H Alpers, G E Dukes, G A Hicks, Neurology and GI Centre of Excellence for Drug Discovery, GlaxoSmithKline, New Frontiers Science Park, Harlow, Essex, UK

Conflict of interest: All authors are or were employees of GlaxoSmithKline.

\section{REFERENCES}

1 Gershon MD. Review article: roles played by 5 -hydroxytryptamine in the physiology of the bowel. Aliment Pharmacol Ther 1999;13(suppl 2):15-30.

2 Galligan JJ. Electrophysiological studies of 5-hydroxytryptamine receptors on enteric neurons. Behav Brain Res 1996;73:199-201.

3 Hicks GA, Coldwell JR, Schindler. Excitation of rat colonic afferent fibres by 5HT(3) receptors. J Physiol 2002;544:861-9.
}

4 Blackshaw LA, Grundy D. Effects of 5-hydroxytryptamine (5-HT) on the discharge of vagal mechanoreceptors and motility in the upper gastrointestinal tract of the ferret. J Auton Nerv Syst 1993;45:51-9.

5 Wade PR, Westfall JA. Ultrastructure of enterochromaffin cells and associated neural and vascular elements in the mouse duodenum. Cell Tissue Res 1985;241:557-63.

6 Erspamer V. Occurence of indolealkylamines in nature. In: Erspamer V, eds. 5-hydroxytryptamine and related indolealkylamines. New York: Springer, 1966:132-81.

7 Gershon MD, Ross LL. Studies on the relationship of 5-hydroxytryptamine and the enterochromaffin cell to anaphylactic shock in mice. J Exp Med 1962; 115:367-82.

8 Chen JX, Pan H, Rothman TP, et al. Guinea pig 5-HT transporter: cloning, expression, distribution, and function in intestinal sensory reception. Am J Physiol 1998;275:G433-48.

9 Blakely RD, Berson HE, Fremeau RT ir, et al. Cloning and expression of a functional serotonin transporter from rat brain. Nature 1991;354:66-70.

10 Wade PR, Chen J, Jaffe B, et al. Localization and function of a 5-HT transporter in crypt epithelia of the gastrointestinal tract. J Neurosci 1996; 16:2352-64.

11 Turvill JL, Farthing MJ. Effect of granisetron on cholera toxin-induced enteric secretion. Lancet 1997;349:1293.

12 Bearcroft CP, Andre EA, Farthing MJ. In vivo effects of the 5-HT3 antagonist alosetron on basal and cholera toxin-induced secretion in the human jejunum: a segmental perfusion study. Aliment Pharmacol Ther 1997;11:1109-14.

13 Sanger GJ, Andrews PLR. Emesis. In: Farthing MJG, Ballinger AB, eds. Drug therapy for gastrointestinal and liver disease. London: Martin Dunitz Ltd, 2001:45-61.

14 Bearcroft CP, Perrett D, Farthing MJ. Postprandial plasma 5hydroxytryptamine in diarrhoea predominant irritable bowel syndrome: a pilot study. Gut 1998;42:42-6.

15 Houghton LA, Atkinson W, Whitaker RP, et al. Increased platelet depleted plasma 5-hydroxytryptamine concentration following meal ingestion in symptomatic female subjects with diarrhoea predominant irritable bowel syndrome. Gut 2003;52:663-70.

16 Camilleri M, Mayer EA, Drossman DA, et al. Improvement in pain and bowel function in female irritable bowel patients with alosetron, a 5-HT3 receptor antagonist. Aliment Pharmacol Ther 1999;13:1149-59.

17 Spiller RC, Jenkins D, Thornley JP, et al. Increased rectal mucosal enteroendocrine cells, T lymphocytes, and increased gut permeability following acute Campylobacter enteritis and in post-dysenteric irritable bowel syndrome. Gut 2000;47:804-11.

18 Moses PL, Coates MD, Mahoney CR, et al. Key elements of serotonin signaling are altered in IBD and IBS: support for a molecular basis of the irritable bowel syndrome. Am J Gastroenterol 2003;98(suppl 1):S262-3.

19 Chen JJ, Li Z, Pan H, et al. Maintenance of serotonin in the intestinal mucosa and ganglia of mice that lack the high-affinity serotonin transporter: Abnormal intestinal motility and the expression of cation transporters. J Neurosci $2001 ; 21: 6348-61$

20 Heils A, Teufel A, Petri S, et al. Allelic variation of human serotonin transporter gene expression. J Neurochem 1996;66:2621-4.

21 Greenberg BD, Tolliver TJ, Huang SJ, et al. Genetic variation in the serotonin transporter promoter region affects serotonin uptake in human blood platelets. Am J Med Genet 1999;88:83-7.

22 Lesch KP, Bengel D, Heils A, et al. Association of anxiety-related traits with a polymorphism in the serotonin transporter gene regulatory region. Science 1996;274:1527-31

23 Little KY, McLaughlin DP, Zhang L, et al. Cocaine, ethanol, and genotype effects on human midbrain serotonin transporter binding sites and mRNA levels. Am J Psychiatry 1998;155:207-13.

24 Pata CEM. Serotonin transporter gene polymorphism in irritable bowel syndrome. Am J Gastroenterol 2002;97:1780-4.

25 Camilleri M, Atanasova E, Carlson PJ, et al. Serotonin-transporter polymorphism pharmacogenetics in diarrhea-predominant irritable bowel syndrome. Gastroenterology 2002;123:425-32.

26 Kim HJ, Atanasova E, Carlson PJ, et al. Serotonin transporter protein polymorphism in lower functional gastrointestinal disorders (FGID). Gastroenterology 2002;120(suppl 1):A504.

27 Ramamoorthy S, Bauman AL, Moore KR, et al. Antidepressant- and cocainesensitive human serotonin transporter: molecular cloning, expression, and chromosomal localization. Proc Natl Acad Sci U S A 1993;90:2542-6.

28 Shen S, Battersby S, Weaver M, et al. Refined mapping of the human serotonin transporter (SLC6A4) gene within 17q11 adjacent to the CPD and NF1 genes. Eur J Hum Genet 2000;8:75-8.

29 Lesch KP, Balling U, Gross J, et al. Organization of the human serotonin transporter gene. J Neural Transm 1994;95:157-62.

30 Battersby S, Ogilvie AD, Blackwood DH, et al. Presence of multiple functional polyadenylation signals and a single nucleotide polymorphism in the $3^{\prime}$ untranslated region of the human serotonin transporter gene. J Neurochem 1999;72:1384-8.

31 Bradley CC, Blakely RD. Alternative splicing of the human serotonin transporter gene. J Neurochem 1997;69:1356-67.

32 Bellivier $\mathbf{F}$, Laplanche $\mathrm{J}$, Leboyer $\mathrm{M}$, et al. Serotonin transporter gene and manic depressive illness: an association study. Biol Psychiatry 1997;41:750-2.

33 Billett EA, Richter MA, King N, et al. Obsessive compulsive disorder, response to serotonin reuptake inhibitors and the serotonin transporter gene. Mol Psychiatry 1997;2:403-6.

34 Bonnet-Brilhault F, Laurent C, Thibaut F, et al. Serotonin transporter gene polymorphism and schizophrenia: an association study. Biol Psychiatry 
35 Collier DA, Arranz MJ, Sham P, et al. The serotonin transporter is a potential susceptibility factor for bipolar affective disorder. NeuroReport 1996;7:1675-9.

36 Cook EH ir, Courchesne R, Lord C, et al. Evidence of linkage between the serotonin transporter and autistic disorder. Mol Psychiatry 1997:2:247-50.

37 Hinney A, Barth N, Ziegler A, et al. Serotonin transporter gene-linked polymorphic region: allele distributions in relationship to body weight and in anorexia nervosa. Life Sci 1997;61:L-303

38 Sander T, Harms $\mathrm{H}$, Lesch KP, et al. Association analysis of a regulatory variation of the serotonin transporter gene with severe alcohol dependence. Alcohol Clin Exp Res 1997;21:1356-9.

39 Offenbaecher M, Bondy B, de Jonge S, et al. Possible association of fibromyalgia with a polymorphism in the serotonin transporter gene regulatory region. Arthritis Rheum 1999:42:2482-8.

40 Ogilvie AD, Battersby S, Bubb VJ, et al. Polymorphism in serotonin transporter gene associated with susceptibility to major depression. Lancet 1996;347:731-3.

41 Osher Y, Hamer D, Benjamin J. Association and linkage of anxiety-related traits with a functional polymorphism of the serotonin transporter gene regulatory region in Israeli sibling pairs. Mol Psychiatry 2000;5:216-19.

42 Sperber AD, Atzmon Y, Neumann L, et al. Fibromyalgia in the irritable bowel syndrome: studies of prevalence and clinical implications. Am J Gastroenterol 1999;94:3541-6

43 Whitehead WE, Palsson O, Jones KR. Systematic review of the comorbidity of irritable bowel syndrome with other disorders: what are the causes and implications? Gastroenterology 2002;122:1140-56.

44 Levy RL, Jones KR, Whitehead WE, et al. Irritable bowel syndrome in twins: heredity and social learning both contribute to etiology. Gastroenterology 2001:121:799-804.

45 Morris-Yates A, Talley NJ, Boyce PM, et al. Evidence of a genetic contribution to functional bowel disorder. Am J Gastroenterol 1998;93:1311-17.

46 Camilleri M, Northcutt AR, Kong S, et al. Efficacy and safety of alosetron in women with irritable bowel syndrome: a randomised, placebo-controlled trial. Lancet 2000;355:1035-40.

47 Camilleri M, Chey WY, Mayer EA, et al. A randomized controlled clinical trial of the serotonin type 3 receptor antagonist alosetron in women with diarrhea-predominant irritable bowel syndrome. Arch Intern Med 2001;161:1733-40.

48 Everhart JE, Renault PF. Irritable bowel syndrome in office-based practice in the United States. Gastroenterology 1991;100:998-1005

49 Saito YA, Schoenfeld P, Locke GR III. The epidemiology of irritable bowel syndrome in North America: a systematic review. Am J Gastroenterol 2002;97:1910-15.

50 SAS release 8.1. Cary, NC: SAS Institute, 2000.

51 Stokes ME, Davis CS, Koch GG. Categorical data analysis using the SAS system. Cary, NC: SAS Institute Inc, 1995.
52 Weir BS. Genetic data analysis II. Sunderland: Sinauer Associates Inc, 1996.

53 Lewontin R. The interaction of selection and linkage. Genetics 1964;49:49-67.

54 Locke GR III, Zinsmeister AR, Talley NJ, et al. Familial association in adults with functional gastrointestinal disorders. Mayo Clin Proc 2000;75:907-12.

55 Collier DA, Stober G, Li T, et al. A novel functional polymorphism within the promoter of the serotonin transporter gene: possible role in susceptibility to affective disorders. Mol Psychiatry 1996;1:453-60.

56 Nielsen DM, Ehm MG, Weir BS. Detecting marker-disease association by testing for Hardy-Weinberg disequilibrium at a marker locus. Am J Hum Genet 1998;63:1531-40.

57 Gelernter J, Cubells JF, Kidd JR, et al. Population studies of polymorphisms of the serotonin transporter protein gene. Am J Med Genet 1999;88:61-6.

58 Gelernter J, Kranzler H, Cubells JF. Serotonin transporter protein (SLC6A4) allele and haplotype frequencies and linkage disequilibria in African- and European-American and Japanese populations and in alcohol-dependent subjects. Hum Genet 1997;101:243-6.

59 Mayer EA, Raybould HE. Role of visceral afferent mechanisms in functional bowel disorders. Gastroenterology 1990;99:1688-704.

60 Mayer EA, Gebhart GF. Basic and clinical aspects of visceral hyperalgesia. Gastroenterology 1994;107:271-93.

61 De Giorgio R, Barbara G, Blennerhassett $P$, et al. Intestinal inflammation and activation of sensory nerve pathways: a functional and morphological study in the nematode infected rat. Gut 2001;49:822-7.

62 McLean PG, Picard C, Garcia-Villar R, et al. Effects of nematode infection on sensitivity to intestinal distension: role of tachykinin NK2 receptors. Eur J Pharmacol 1997;337:279-82.

63 Al Chaer ED, Westlund KN, Willis WD. Sensitization of postsynaptic dorsal column neuronal responses by colon inflammation. NeuroReport 1997; 8:3267-73

64 Al Chaer ED, Kawasaki M, Pasricha PJ. A new model of chronic visceral hypersensitivity in adult rats induced by colon irritation during postnatal development. Gastroenterology 2000;1 19:1276-85.

65 Coutinho SV, Meller ST, Gebhart GF. Intracolonic zymosan produces visceral hyperalgesia in the rat that is mediated by spinal NMDA and non-NMDA receptors. Brain Res 1996:736:7-15

66 Coutinho SV, Plotsky PM, Sablad M, et al. Neonatal maternal separation alters stress-induced responses to viscerosomatic nociceptive stimuli in rat. Am J Physiol Gastrointest Liver Physiol 2002;282:G307-16.

67 Gue M, Rio-Lacheze C, Eutamene H, et al. Stress-induced visceral hypersensitivity to rectal distension in rats: role of CRF and mast cells. Neurogastroenterol Motil 1997;9:271-9.

68 Gunter WD, Shepard JD, Foreman RD, et al. Evidence for visceral hypersensitivity in high-anxiety rats. Physiol Behav 2000;69:379-82.

\section{Sir Francis Avery Jones BSG Research Award 2005}

Applications are invited by the Education Committee of the British Society of Gastroenterology, who will recommend to Council the recipient of the 2005 award. Applications (20 copies) should include:

- a manuscript (two A4 pages only) describing the work conducted

- a bibliography of relevant personal publications

- an outline of the proposed content of the lecture, including title

- a written statement confirming that all or a substantial part of the work has been personally conducted in the UK or Eire.

Entrants must be 40 years or less on 31 December 2005, but need not be a member of the society. The recipient will be required to deliver a 30 minute lecture at the annual meeting of the society in Birmingham in March 2005. Applications (20 copies) should be made to the Honorary Secretary, British Society of Gastroenterology, 3 St Andrews Place, London NW1 4 LB by 1 December 2004. 